\title{
APLIKASI KONVERTER KALIMAT AKTIF-PASIF BERBASIS ANDROID
}

\author{
Asih Pujiastuti ${ }^{1}$, Nurcahyani Dewi Retnowati ${ }^{2}$, Nurwahiddatur Rohman ${ }^{3}$ \\ Departemen Teknik Informatika \\ Sekolah Tinggi Teknologi Adisutjipto \\ informatika@stta.ac.id
}

\begin{abstract}
Active-Passive Sentences Converter is an android-based application that aims to transform active sentences into passive voice, it's expected to facitate help elementary school children especially in particular to transform the active-passive sentences. The system on the application does not work if the entered sentences does not meet the S-P-O element, and for the predicate is not the same as the active verb. If the user has entered the sentence in accordance with the standard active sentence then system will move the object on the active sentence into the subject on the passive sentence as well as the subject becomes the object, and replace the active verb into a passive verb with the particle di- on the predicate. This application can only be operated at least on 4.4 Kitkat android version. The result of the application tested was awesome with the 92\% of correct percentage, after applied at three elementary schools are SD Jomblangan, SDN Adisucipto, SDIT Salsabila Al Muthi'in, SDN Berbah 1 and SD Muhammadiyah Noyokerten.
\end{abstract}

Keywords: Converter, Active-Passive, Sentences

\section{Latar Belakang}

Bahasa merupakan aspek terpenting dalam kehidupan manusia yang dikenal sebagai makhluk sosial baik secara lisan maupun tulisan. Ada dua pengertian bahasa yaitu: Pertama, menyatakan bahasa sebagai alat komunikasi antara anggota masyarakat berupa simbol bunyi yang dihasilkan oleh alat ucap manusia. Kedua, bahasa adalah sistem komunikasi yang mempergunakan simbol-simbol vokal (bunyi ujaran) yang bersifat arbitrer [1].

Kalimat aktif merupakan sebuah kalimat dengan subjek (S) berperan sebagai pelaku secara aktif yang melakukan suatu tindakan yang dinyatakan dalam predikat (P) kepada objek (O). Sedangkan, jika subjek (S) suatu kalimat yang tidak berperan sebagai pelaku, tetapi sebagai sasaran perbuatan yang dinyatakan predikat $(\mathrm{P})$ maka disebut kalimat pasif [2].

Kalimat-kalimat aktif dapat dijadikan kalimat pasif dengan mengubah unsur objek (O) dijadikan subjek (S), dan hal itu akan mengakibatkan perubahan bentuk verba predikat berawalan memenjadi berawalan di-. Pengubahan ini menyebabkan perubahan bentuk verba pengisi predikat $(\mathrm{P})$, yaitu verba aktif menjadi verba pasif.

Terjadinya perpindahan struktur kalimat dari kalimat aktif menjadi kalimat pasif, serta adanya pergantian atau perubahan kata pada predikat yang terkadang membuat bingung sebagian orang khususnya siswa sekolah dasar.

Berdasarkan permasalahan di atas maka dilakukan penelitian dengan judul Aplikasi Konverter Kalimat Aktif-Pasif berbasis android. Sehingga diharapkan aplikasi ini bisa membantu atau mendukung siswa dalam mengubah kalimat aktif menjadi kalimat pasif. Kinerja perancangan aplikasi ini, pengguna mengisikan sebuah kalimat yang akan dikonversi. Selanjutnya, sistem akan melakukan perubahan kalimat aktif menjadi pasif. 


\section{Kajian Pustaka}

Penelitian yang dilakukan oleh Algani, dkk., 2014 [3], yang berjudul "The Ability To Change Active Sentence Into Passive Sentence Student Class X MA Gisting". Masalah yang dibahas pada penelitian ini adalah kemampuan mengubah kalimat aktif menjadi kalimat pasif siswa kelas X MA Gisting. Penelitian bertujuan mendeskripsikan kemampuan mengubah kalimat aktif menjadi kalimat pasif. Metode penelitian dalam penelitian ini menggunakan metode penelitian deskriptif. Sumber data dalam penelitian berupa kalimat siswa yang berjumlah 35 siswa. Hasil penelitian menyatakan bahwa tingkat kemampuan siswa MA Gisting dalam mengubah kalimat aktif menjadi kalimat pasif tergolong pada kategori baik dengan skor rata-rata 73,65. Skor rata-rata per aspek yakni aspek ketepatan struktur pembentukan kalimat pasif 77,22 tergolong kategori baik dan pada aspek kebahasaan (ejaan) skor rata-ratanya adalah 69,37 tergolong kategori cukup.

\section{Metodologi Penelitian}

\subsection{Kalimat Aktif-Pasif}

Kalimat aktif merupakan sebuah kalimat dengan subjek (S) berperan sebagai pelaku secara aktif yang melakukan suatu tindakan yang dinyatakan dalam predikat (P) kepada objek (O). Sedangkan, jika subjek (S) suatu kalimat yang tidak berperan sebagai pelaku, tetapi sebagai sasaran perbuatan yang dinyatakan predikat $(\mathrm{P})$ maka disebut kalimat pasif.

Ciri-ciri kalimat aktif adalah sebagai berikut:

1. Subjek melakukan suatu perbuatan yang langsung mengenai objeknya.

2. Predikat selalu diawali dengan imbuhan me- atau ber-.

3. Struktur kalimat minimal S-P-O

Ciri-ciri kalimat pasif adalah sebagai berikut:

1. Subjek pada kalimat aktif menjadi objek pada kalimat pasif.

2. Predikat diawali dengan imbuhan di-.

Perubahan kalimat aktif menjadi kalimat pasif dengan kata kerja tulis sebagai berikut:

Kata kerja $=$ Tulis.

$$
\text { Kalimat aktif }=\frac{\text { Susi }}{\mathrm{S}} \frac{\text { Menulis }}{\mathrm{P}} \frac{\text { Puisi }}{\mathrm{O}}
$$

Pada kalimat aktif di atas, untuk predikat atau kata kerja terjadi perubahaan bunyi dengan menambahkan me- diawal kata kerja tulis, sehingga huruf T disenyapkan menjadi huruf $\mathrm{N}$.

Untuk menjadikannya kalimat pasif maka struktur kalimat subjek berpindah menjadi objek pada kalimat aktif serta untuk kata kerja ditambah imbuhkan di-.

$$
\text { Kalimat pasif }=\frac{\text { Puisi }}{S} \frac{P}{P} \frac{S}{P} \frac{\text { Ditulis }}{P} \frac{\text { Susi }}{O}
$$

\subsection{Perancangan Sistem}

Untuk membangun aplikasi tersebut diperlukan adanya analisa perancangan sistem terlebih dahulu seperti pembutan use case diagram, activity diagram, class diagram, dan sequence diagram. 


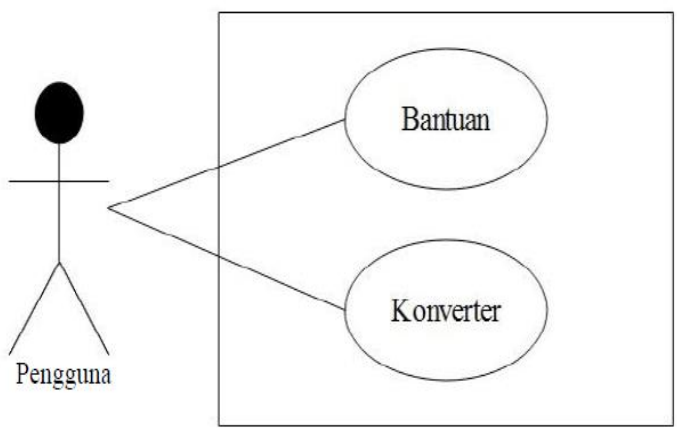

\section{Gambar 1. Use Case Diagram Pengguna}

Gambar 1 menjelaskan use case diagram pengguna bahwa aktivitas yang bisa dikerjakan pengguna terhadap sistem adalah memilih bantuan, dan memilih konverter.

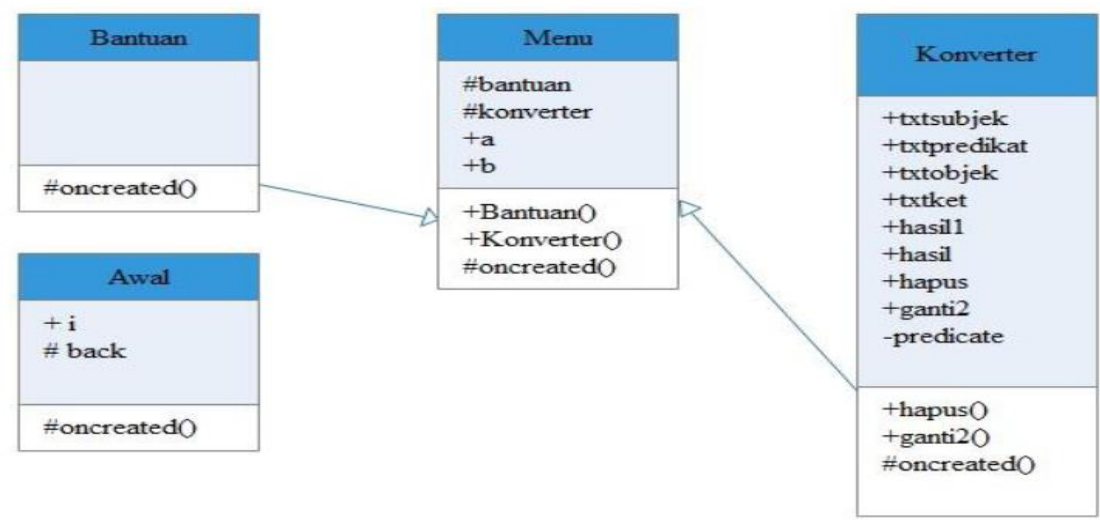

Gambar 2. Class Diagram Aplikasi Konverter Aktif-Pasif

Pada Gambar 2 menjelaskan alur class pada aplikasi Konverter Kelimat Aktif Pasif. Terdapat empat class yakni tampilan awal, home, bantuan dan konverter. Untuk class tampilan awal berdiri sendiri, jadi tidak terhubung dengan class yang lain, sedangkan untuk class home terhubungan dengan dua class lainnya seperti bantuan dan konverter.

Pada class bantuan hanya berisikan penjelasan singkat tentang kalimat aktif-pasif, serta aturan dalam penggunaan aplikasi. Sedangkan untuk class konverter ada beberapa atribut di dalamnya seperti subjek, predikat, objek dan keterangan guna diisi oleh pengguna untuk menjadikannya kalimat aktif yang nantinya akan diproses dengan proses konverter untuk diubah dari kalimat aktif menjadi kalimat pasif, ada proses lainnya pada class konverter yakni hapus data, untuk menghapus isi teks pada masing-masing atribut.

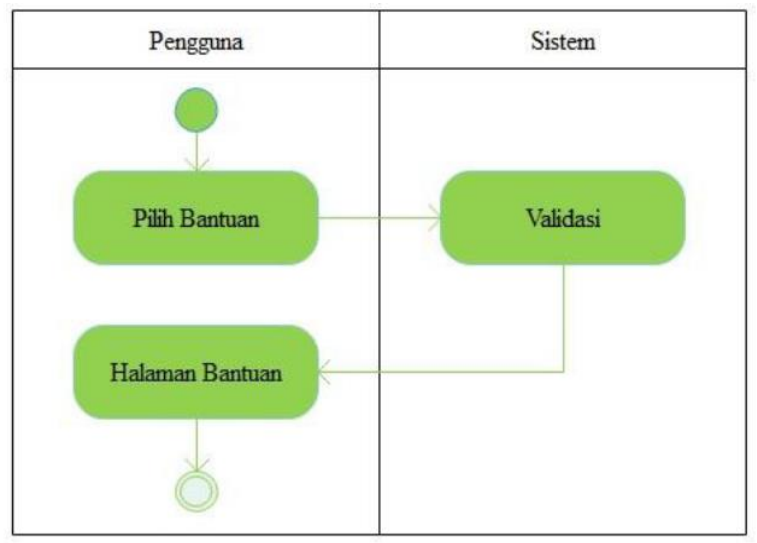

Gambar 3. Activity Diagram Bantuan 
Pada Gambar 3 menjelaskan alur pengguna dari memilih bantuan, kemudian akan tampil form tentang penjelasan singkat kalimat aktif-pasif, serta terdapat beberapa informasi untuk pennggunaan aplikasi Konverter Kalimat Aktif-Pasif.

Pada Gambar 4 menjelaskan alur pengguna dari memilih proses konverter, kemudian akan tampil form konverter yang harus diisi oleh pengguna yakni mengisi struktur kalimat minimal S-P$\mathrm{O}$ dengan predikat sama dengan kata kerja. Jika tidak memenuhi kriteria tersebut maka proses tidak akan berjalan dan pengguna harus mengganti atau mengisi struktur yang masih kosong. Jika kriteria sudah terpenuhi maka sistem akan melakukan perubahan kalimat aktif menjadi kalimat aktif, dan kalimat aktif akan diterima oleh pengguna.

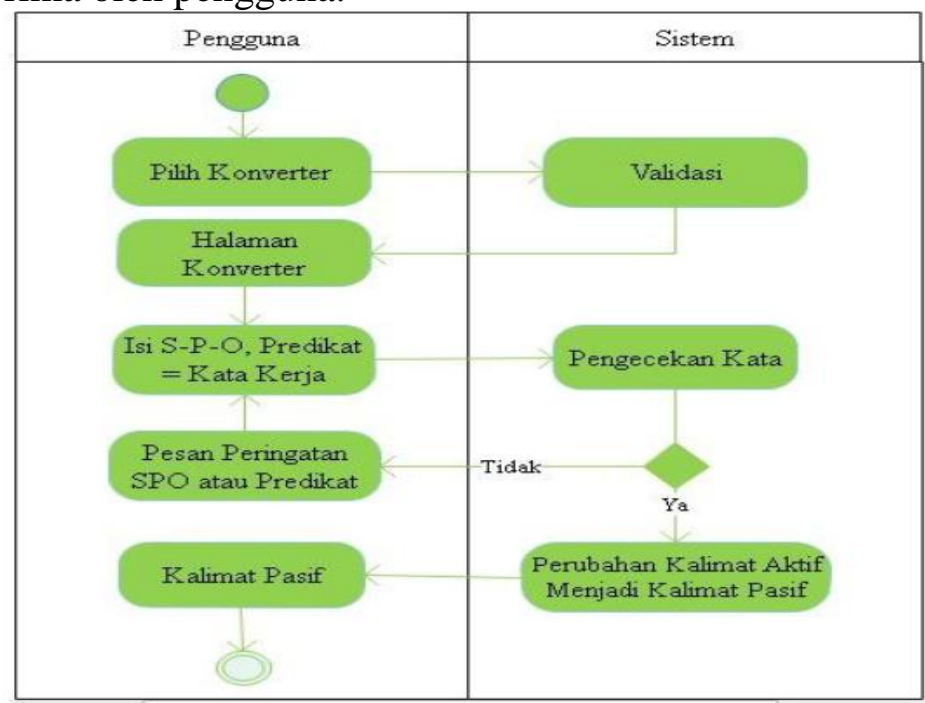

\section{Gambar 4. Activity Diagram Konverter}

Pada Gambar 5, pengguna aplikasi mengakses aplikasi untuk mengoperasikan sistem dengan terlebih dahulu akan ada dua menu yang harus pengguna pilih. Ketika pengguna memilih mengakses bantuan terlebih dahulu maka untuk form menu akan tersembunyi dan harus kembali ke menu untuk mengakses konverter. Pada konverter akan terjadi pengecekkan data jika kalimat tidak memenuhi struktur S-P-O atau predikat tidak sama dengan yang tersimpan maka pengguna akan menerima pesan kesalahan. Namun, jika pengguna telah mengisi sesuai dengan aturan aplikasi maka kalimat aktif akan digantikan kalimat pasif dan diterima oleh pengguna.

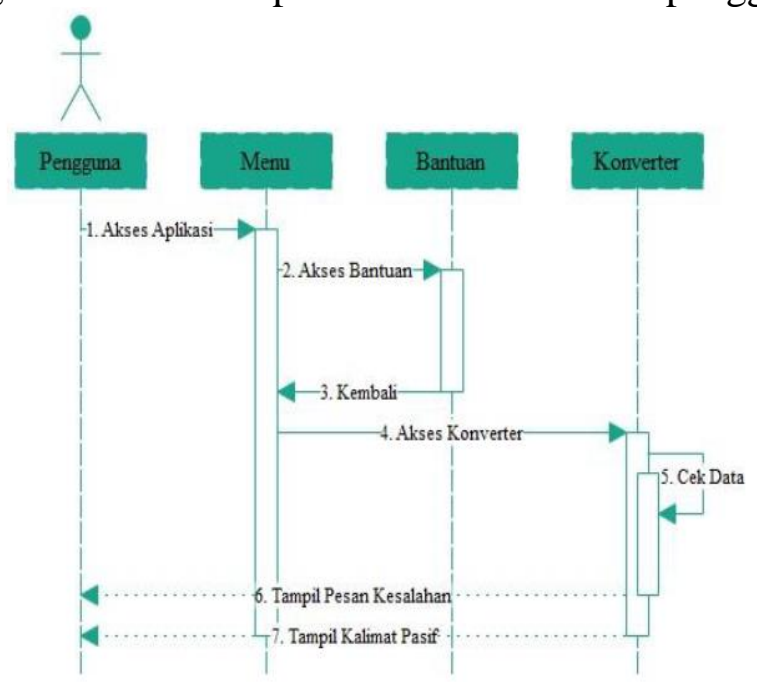

Gambar 5. Sequence Diagram Pengguna Aplikasi 


\section{Implementasi Dan Pengujian}

\subsection{Implementasi}

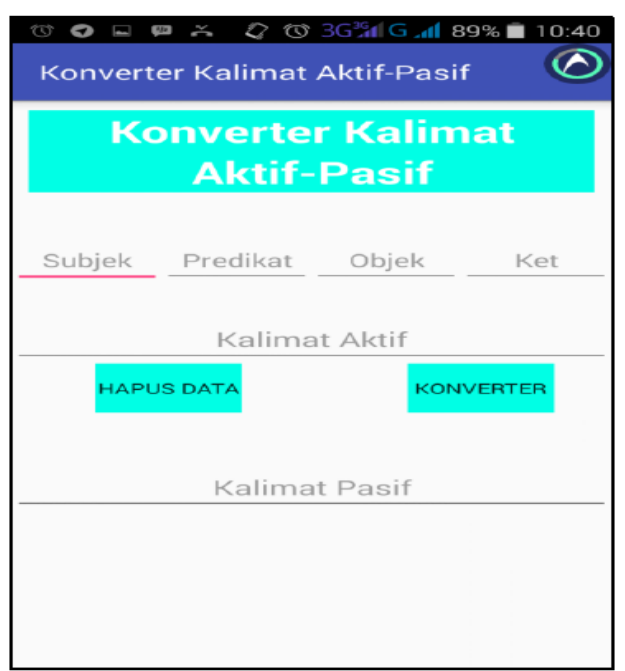

Gambar 6. Halaman Konverter

Pada Gambar 6 merupakan tampilan halaman konverter dengan tampilan empat unsur kalimat yakni subjek, predikat, objek dan keterangan. Pengguna hanya harus mengisi minimal memenuhi unsur S-P-O. Jika kurang dari S-P-O maka akan ada peringatan seperti pada Gambar 7.
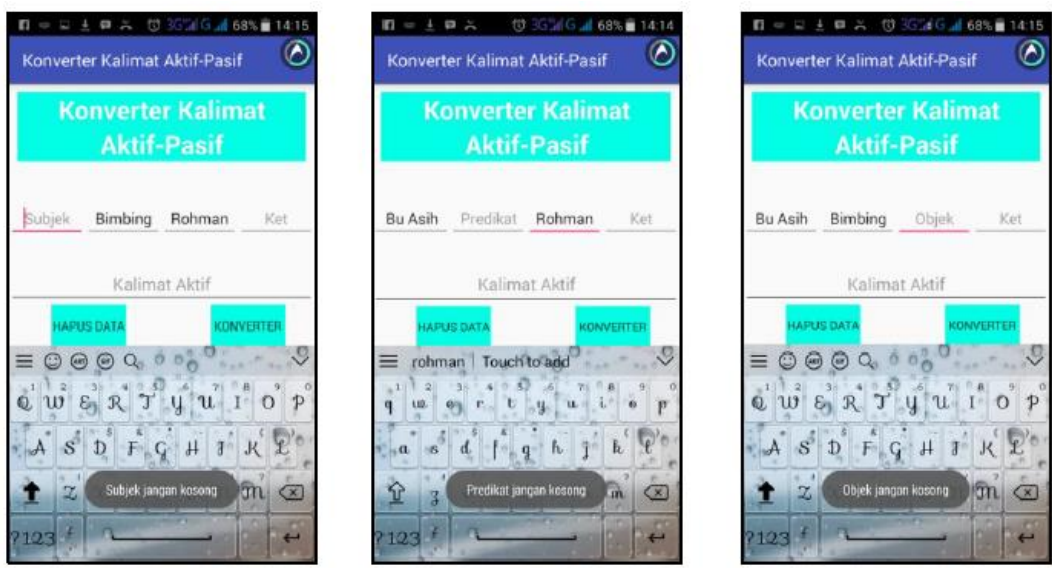

Gambar 7. Peringatan Unsur Kalimat Tidak Terpenuhi

Selain peringatan karena unsur kalimat yang tidak terpenuhi, sistem akan mengeluarkan peringatan ketika pengisian predikat tidak sesuai dengan data_predikat.txt, data tersebut tersimpan pada directory raw.

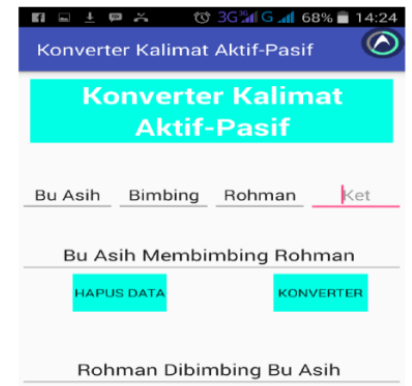

Gambar 8. Hasil Konverter 
Dari Gambar 8 Hasil Konverter telihat bahwa sistem sudah berhasil untuk mengganti kalimat aktif menjadi kalimat pasif yang sesuai dengan tujuan dibuatnya aplikasi ini.

Untuk koding program hasil konverter dari aplikasi konverter kalimat aktif-pasif seperti pada Gambar 8 adalah sebagai berikut:

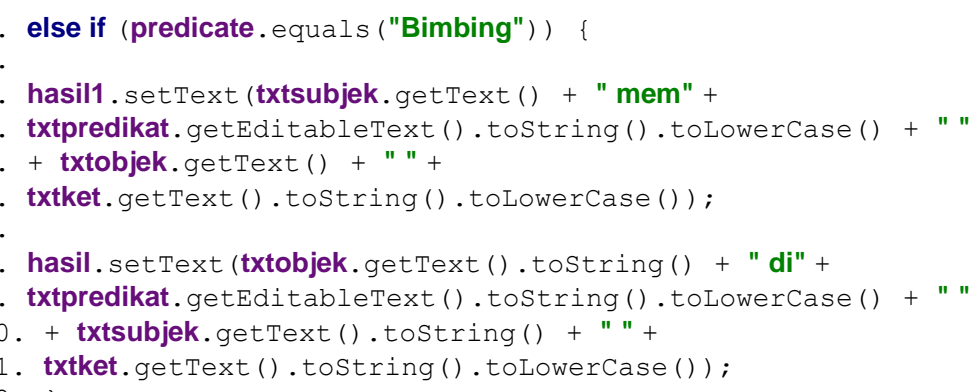

Koding program di atas merupakan masih koding lanjutan dari peringatan S-P-O dan peringatan predikat. Pada baris 1 menjelasan jika pengguna memasukan predikat "Bimbing" menyesuaikan pada Gambar 8, maka untuk output atau hasil dari kalimat aktif bisa dilihat pada baris 3 sampai 6. Yakni untuk hasill. yang merupakan nama lain dari kolom kalimat aktif akan mengatur masukan dengan memaggil input-an subjek terlebih dahulu, lalu predikat dengan imbuhan mem- didepannya, terus memanggil objek dan keterangan jika ada. Sedangkan untuk output atau hasil kalimat pasif bisa dilihat pada baris ke 8 sampai 11, untuk koding tidak terlalu beda, hanya pada pemanggil unsur kalimat apa yang didahulukan.

Pada kalimat pasif maka input-an objek akan menjadi subjek pada kalimat pasif, dilanjutkan dengan predikat yang mendapatkan imbuhan di- didepannya, lalu memanggil subjek untuk dijadikan objek yang terakhir keterangan.

Selanjutnya pada button hapus data jika ditekan akan menghasilkan seperti tampilan awal dengan semua struktur kalimat serta kalimat aktif-pasif belum terisi.

\subsection{Pengujian}

\subsubsection{Pengujian OS}

Setelah melakukan pengujian OS (Operation System) pada android yang berbeda dengan tujuan untuk mengetahui apakah aplikasi bisa dioperasikan sebagaimana mestinya atau tidak, didapatkan hasil bahwa android dengan minimum versi 4.4 Kitkat yakni versi 5.0 Lolipop, versi 6.0 Marsmallow, dan versi 7.0 Nuget bisa mengoperasikan aplikasi dengan baik. Berikut daftar smartphone yang telah digunakan untuk mengoperasikan Aplikasi Konverter Kalimat Aktif Pasif, di antaranya:

Tabel 1. Hasil Pengujian OS

\begin{tabular}{|c|c|}
\hline Nama Perangkat dan OS & Keterangan \\
\hline $\begin{array}{c}\text { Advan S4A } \\
\text { (Android V4.2 Jelly Bean) }\end{array}$ & $\mathrm{X}$ \\
\hline $\begin{array}{c}\text { Samsung Galaxy } \\
\text { (Android V4.2 Jelly Bean) }\end{array}$ & $\mathrm{X}$ \\
\hline $\begin{array}{c}\text { Himax Polymer } \\
\text { (Android V4.4 Kitkat) }\end{array}$ & $\checkmark$ \\
\hline $\begin{array}{c}\text { Asus Zenfone 2 } \\
\text { (Android V5.0 Lolipop) }\end{array}$ & $\sqrt{ }$ \\
\hline $\begin{array}{c}\text { Oppo F1s } \\
\text { (Android V5.1 Lolipop) }\end{array}$ & $\checkmark$ \\
\hline $\begin{array}{c}\text { Samsung Galaxy S7 Edge } \\
\text { (Android V6.0 Marsmallow) }\end{array}$ & $\checkmark$ \\
\hline $\begin{array}{c}\text { Xiaomi 3S Pro } \\
\text { (Android V7.0 Nuget) }\end{array}$ & $\checkmark$ \\
\hline $\begin{array}{l}\text { Keterangan: } \\
\text { X: Tidak bisa digunakan } \\
\text { V: Bisa digunakan }\end{array}$ & \\
\hline
\end{tabular}




\subsubsection{Analisa Hasil Pengujian}

Pada analisa hasil pengujian kode program ini yakni memastikan bahwa kode program sudah bisa beroperasi atau berfungsi sebagaimana mestinya dengan Tabel 2 Kata Kerja sebagai acuan pengujian dari sebagian kata kerja yang ada pada aplikasi.

Tabel 2. Kata Kerja

\begin{tabular}{|c|c|c|}
\hline Kata Kerja Dasar & Kata Kerja Aktif & Kata Kejja Pasif \\
\hline Ajar & Mengajar & Diajar \\
\hline Ajak & Mengajak & Diajals \\
\hline Buka & Membuka & Dibuka \\
\hline Beli & Membeli & Dibeli \\
\hline Cuci & Mencuci & Dicuci \\
\hline Cubit & Mencubit & Dicubit \\
\hline Dorong & Mendorong & Didorong \\
\hline Edit & Mengedit & Diedit \\
\hline Elus & Mengeuns & Dielus \\
\hline Geser & Menggeser & Digeser \\
\hline Gosolk & Menggosolk & Digosolk \\
\hline Ibat & Mengikat & Dikat \\
\hline
\end{tabular}

Berikut hasil dari pengujian sesuai dengan beberapa kata kerja yang ada pada Tabel 2. Pada Gambar 9 Pengujian Pertama dengan kata kerja ajar.

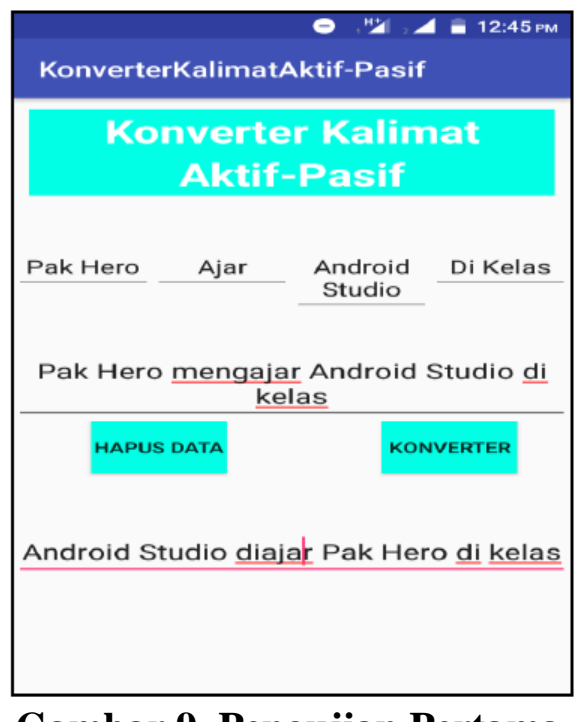

\section{Gambar 9. Pengujian Pertama}

Pada Gambar 9 untuk subjek diisi dengan Pak Hero, untuk predikat diisi Ajar, untuk objek diisi Android Studio dan yang terakhir diisi Di Kelas. Ketika pengguna menekan button Konverter maka akan keluar hasil untuk kalimat aktif dan pasif. Untuk kalimat aktif berupa, "Pak Hero mengajar Android Studio di kelas". Sedangkan untuk kalimat pasif berupa, "Android Studio diajar Pak Hero di kelas". 
Selanjutnya pada Gambar 10 Pengujian Kedua dengan kata kerja beli. Untuk subjek diisi Bu Astika dengan predikat Beli dan Objek diisi Jilbab Baru. Untuk hasil kalimat aktif berupa, "Bu Astika membeli Jilbab Baru". Sedangkan kalimat pasifnya berupa, "Jilbab Baru dibeli Bu Astika".

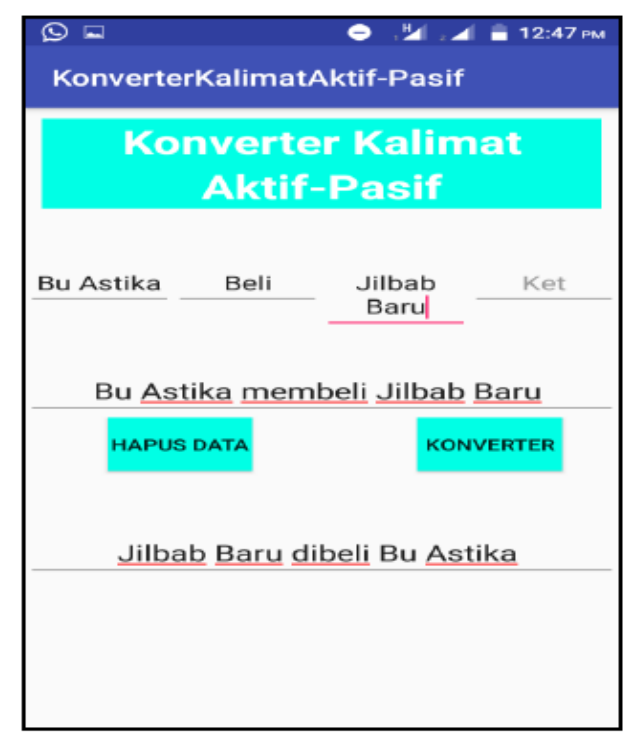

Gambar 10. Pengujian Kedua

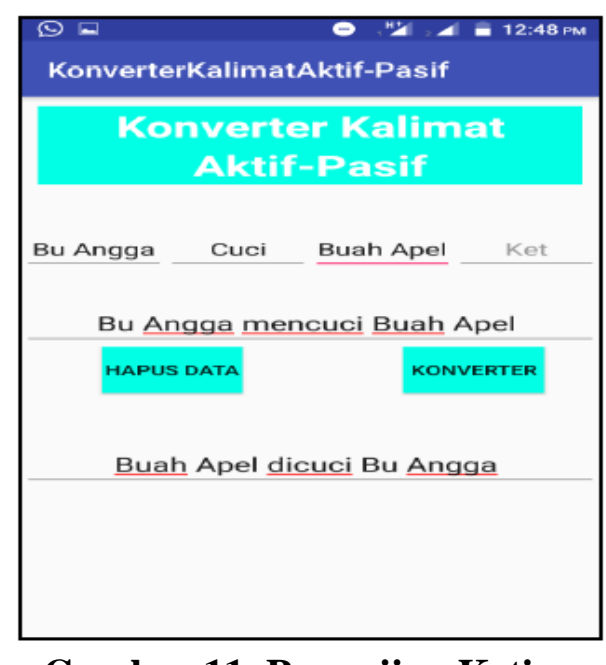

Gambar 11. Pengujian Ketiga

Pada Gambar 11 Pengujian Ketiga dengan kata kerja cuci. Pada subjek diisi Bu Angga dengan predikat Cuci dan objek Buah Apel. Maka akan menghasilkan kalimat aktif berupa, "Bu Angga mencuci Buah Apel". Sedangkan untuk kalimat pasifnya berupa, "Buah Apel dicuci Bu Angga".

\subsubsection{Pengujian Pengguna}

Hasil pengujian menggunakan kuisioner dengan responden berjumlah 10 orang yang merupakan guru sekolah dasar di SD Jomblangan, SDN Adisucipto, SDIT Salsabila Al-Muthiein, SDN Berbah 1 dan SD Muhammadiyah Noyokerten, hasil pengujian aplikasi yang telah dilakukan, maka diperoleh nilai 92\% sehingga aplikasi ini dikategorikan SANGAT BAIK. 


\section{Kesimpulan Dan Saran}

\subsection{Kesimpulan}

Kesimpulan dari penelitian ini adalah sebagai berikut:

1. Aplikasi mampu mengubah kalimat aktif menjadi kalimat pasif.

2. Aplikasi bisa dioperasikan pada android dengan minimum versi 4.4 Kitkat.

3. Aplikasi mendapatkan respon positif dari beberapa pengajar sekolah dasar, dari kuisioner yang dilakukan bersama sepuluh responden pada lima sekolah dasar diperoleh hasil $92 \%$ sehingga aplikasi ini dikategorikan sangat baik.

\subsection{Saran}

Saran untuk pengembangan dari penelitian ini adalah sebagai berikut:

1. Aplikasi ini dapat dikembangkan ke sistem operasi lain seperti IOS, windows phone, dan desktop sehingga bisa digunakan pada laptop untuk proses belajar di sekolah.

2. Untuk predikat dapat dikembangkan menjadi auto-corection, sehingga begitu ada kesalahan pengetikan maka data akan terganti secara otomatis.

\section{DAFTAR PUSTAKA}

[1] Keraf, Samapra. 2005. Kadhipta. Jakarta: Balai Pustaka.

[2] Sugono, Dendy. 2009. Mahir Berbahasa Indonesia Dengan Benar. Jakarta: PT. Gramedia Pustaka Utama.

[3] Algani Makmum, Imam Rejana, Eka SF, 2014. The Ability To Change Active Sentence Into Passive Sentence Student Class X MA Gisting. Jurnal Kata.

[4] Badudu. 1994. Kamus Besar Bahasa Indonesia. Jakarta: Depdiknas.

[5] Kridalaksana, Harimurti. 2001. Kamus Linguistik. Jakarta: Gramedia Pustaka Utama.

[6] Nugroho, Adi. 2010. Rekayasa Perangkat Lunak Menggunakan UML dan Java. Yogyakarta: Andi Publisher.

[7] Darmadi, Hamid. 2011. Metode Penelitian Pendidikan. Bandung: Penerbit Alfabeta. 